\title{
PERAN IBU RUMAH TANGGA PEKERJA BURUH KASAR DALAM MENINGKATAN KONDISI SOSIAL EKONOMI KELUARGA (Studi Pada PT. CAM Di Desa Bumi Raya Kecamatan Andoolo Kabupaten Konawe Selatan)
}

Irmawati ${ }^{1}$, Muhammad Rusli ${ }^{2}$, Megawati Asrul Tawulo ${ }^{3}$

${ }^{123}$ Universitas Halu Oleo

Email: Irmawatiirmawati98@gmail.com, muh.rusli@ac.id, megawatiasrultawulo@gmail.com

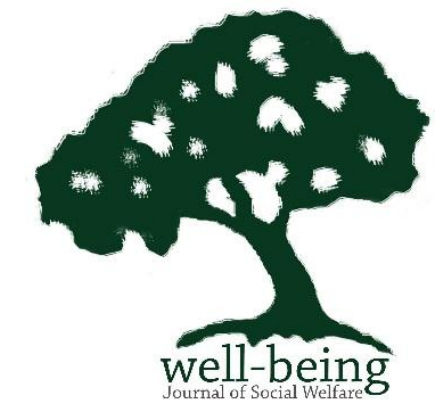

\section{ABSTRAK}

This study aims to determine how the role of housewives of unskilled laborers at PT. CAM and to find out how the socioeconomic conditions of housewives who work at PT. CAM. This type of research is a qualitative descriptive study. The data collection technique was carried out by means of observation, interview and documentation with 7 housewives in Bumi Raya Village, Andoolo District who worked at PT. CAM. The results showed that the housewives of unskilled laborers at PT. CAM continues to carry out its duties as a housewife, namely caring for and educating her children, being her husband's partner, being a family manager, being a family finance minister, being a role model for her children, being a nurse for her family. And the socio-economic conditions of the family who work at PT. CAM is good enough, this is shown through indicators of meeting family needs / expenditure, income, housing but not for educational indicators where the education of housewives who work at PT. CAM is still relatively low, namely only elementary or junior high school graduates.

Keywords: Role of Housewives, Unscrupulous Labor, Family Socio-Economic Conditions

\section{PENDAHULUAN}

Persoalan yang cukup mengemuka dalam perkembangan era modern adalah semakin meningkatnya tingkat kebutuhan hidup sehari-hari baik secara individual maupun keluarga. Masyarakat yang melangkah maju ke zaman baru seperti zaman kini, mengalami masa emansipasi (pembebasan) dari sistem kekrabatan tradisional untuk mendapatkan status baru sesuai dengan zaman baru, dalam keluarga dan dalam masyrakat besar.

Peranan dan keikutsertaan perempuan dalam dunia kerja telah berhasil memberikan kontribusi cukup besar terhadap kesejahteraan keluarga, khususnya dibidang ekonomi. Jumlah perempuan yang bekerja di negara Indonesia maupun di negara lain akan terus meningkat, seiring dengan semakin meningkatnya kesempatan belajar untuk perempuan, keberhasilan program pemerintah di bidang keluarga berencana, serta semakin canggihnya teknologi guna mendukung dua peran perempuan yaitu peran domestik dan peran publiknya sehingga dapat meningkatkan kondisi sosial ekonomi keluarga. Peningkatan perempuan untuk bekerja tidak hanya mempengaruhi konstelasi pasar kerja, tetapi juga memperhatikan perekonomian dan kesejahteraan perempuan itu sendiri maupun keluarganya. Semakin meningkatnya pendapatan ibu rumah tangga maka semakin meningkat pula kondisi sosial ekonomi keluarga.

Dalam Maria (2002: 22) setiap individu dalam masyarakat memiliki perannya masing-masing. Satu sama lain relatif berbeda tergantung pada kapasitasnya. Begitu pula dalam sebuah keluarga. Seorang anak tidak mungkin berperan sama dengan bapak dan ibunya.

Dengan peran ibu yang dominan dan optimal dalam suatu keluarga yang mencakup tugas pokok seorang ibu sebagai pengurus rumah tangga dan juga perannya dalam perekonomian keluarga, 
serta dalam kehidupan sosial masyarakatnya dapat mempengaruhi kondisi sosial ekonomi keluarga. Jika kondisi sosial ekonomi keluarga tercapai dengan baik, maka akan berpengaruh pula terhadap tingkat pendidikan anak. Semakin baik kondisi sosial ekonomi suatu keluarga, maka pendidikan anak akan terpenuhi dengan baik. Begitu juga bila kondisi sosial ekonomi keluarga dan pendidikan anak terpenuhi dengan baik, maka akan tercapailah keluarga yang sejahtera.

Dalam Maria (2002 :38-40)

dalam masyarakat kita, ibu cenderung menjadi teman dan pendidikan pertama bagi anak selain mengurus wilayah domestik keluarga, ibu juga berperan sebagai salah satu anggota kelompok dari peranan sosialnya serta sebagai anggota masyarakat dari lingkunganya. Peran ibu bagi keluarganya adalah sebagai berikut: Pengasuh dan pendidik anak, Partner ayah, Manajer keluarga, Mentri keuangan keluarga, Pemberi tauladan, Perawat keluarga

Ibu rumah tangga memiliki peran yang penting dalam menyiasati serta mengatasi kemiskinan yang ada dalam keluarganya. Hal ini terlihat pada Ibu rumah tangga di Desa Bumi Raya Kecamatan Andoolo Kabupaten Konawe Selatan yang bekerja sebagai buruh kasar pada PT. Cipta Agung Manis (CAM). Dimana sebagian besar ibu rumah tangga memilih ikut bekerja untuk membantu suami mencari nafkah tanpa meninggalkan tugasnya sebagai seorang istri.

Dengan demikian para ibu rumah tangga yang bekerja bisa meningkatkan kondisi sosial ekonomi keluarganya. Dalam penelitian Dalam penelitian Wurdiyanti (2016: 13) kondisi sosial ekonomi yang baik dapat di ukur dari pendidikan, pendapatan/penghasilan keluarga, keadaan rumah, dan pemenuhan kebutuhan keluarga/pengeluaran keluarga.
Dalam Maria (2002:9-12) keluarga menjadi bagian terpenting dalam sistem sosial kemasyarakatan, bahkan dalam sistem ekonomi. Meski keberadaanya merupakan bagian terkecil, tetapi keluarga memiliki peran sebagai kunci. Tanpa adanya keluarga, sistem sosial tidak akan terbentuk. Hal ini karena terbentuknya sebuah masyarakat dimulai dari adanya keluarga.

Selain menjadi kunci terbentuknya sistem sosial, keluarga juga berperan penting membentuk karakter individu dalam sebuah masyarakat. Untuk itu, takheran jika masing-masing anggota keluarga saling memperhatikan pendidikan, kesehatan, gaya hidup, dan lain sebagainya, misalnya seorang ayah memperhatikan kesejahteraan dan pendidikan keluarganya (istri dan anak), ibu memperhatikan pola makan dan pendidikan keluarganya (suami dan anak), anak memperhatikan kesehatan keluargnya (bapak dan ibu). Dalam hal ini, semua anggota keluarga seperti terkait satu sama lain.

Wawancara awal yang dilakukan peneliti kepada pengawas lapangan di PT. Cipta Agung Manis yaitu Ibu Ela. Menurut pemaparanya mereka rata-rata ikut terjun di sektor publik yakni sebagai buruh kasar dengan sistem borongan. Dimana sebagian besar istri yang bekerja di PT. Cipta Agung Manis (CAM) tersebut suaminya bekerja sebagai petani, buruh bangunan, karyawan lapangan pada PT. Cipta Agung Manis (CAM), dan lain sebagainya yang memiliki penghasilan terbilang rendah. Dimana banyak para ibu rumah tangga khususnya di Desa Bumi Raya yang bekerja di PT. Cipta Agung Manis (CAM) tersebut karena penghasilan suami yang tidak mencukupi kebutuhan keluarga sehingga istri juga ikut bekerja untuk memenuhi kebutuhan keluarga. Berdasarakan data awal tersebut maka menarik untuk dilakukan penelitian 
lanjutan untuk mengkaji secara empirik dan ilmiah tentang Peran Ibu Rumah Tangga Pekerja Buruh Kasar Dalam Meningkatkan Kondisi Sosial Ekonomi Keluarga (Studi Pada PT. Cipta Agung Manis CAM di Desa Bumi Raya Kecamatan Andoolo Kabupaten Konawe Selatan)

\section{METODE PENELITIAN}

Jenis penelitian yang dilakukan oleh penulis adalah penelitian deskriptif kualitatif. Jenis penelitian ini untuk memberikan gambaran atau menjelaskan secara detail mengenai peran ibu rumah tangga pekerja buruh kasar pada PT. CAM dan kondisi sosial ekonomi keluarga yang bekerja pada PT. CAM.

Informan penelitian dalam penelitian ini adalah para ibu rumah tangga pekerja buruh kasar di Desa Bumi Raya Kecamatan Andoolo Kabupaten Konawe Selatan yang bekerja pada PT. Cipta Agung Manis (CAM) yang berjumlah 7 orang. Adapun pemilihan informan dilakukan dengan teknik purposive sampling penunjukan langsung kepada subyek yang dianggap memiliki pengetahuan tentang permasalahan yang akan diteliti yaitu peran ibu rumah tangga pekerja buruh kasar dalam meningkatkan kondisi sosial ekonomi.

\section{HASIL DAN PEMBAHASAN}

1. Peran Ibu Rumah Tangga Pekerja Buruh Kasar Pada PT. Cipta Agung Manis (CAM) Dalam Meningkakan Kondisi Sosial Ekonomi Keluarga

a. Peran Domestik/Reproduktif

1) Mengasuh dan Mendidik Anak

Selain sebagai pengasuh, ibu juga berperan sebagai pendidik pertama anakanak mereka. Sebelum anak-anak mereka keluar rumah, ibulah orang terdekat yang berperan sebagai guru dalam mengajari anak-anaknya. Berikut pernyataan dari informan atas nama ibu Rina yaitu:

anak saya ada yang umur 6 tahun yang paling kecil masih kelas 1
SD terus dia sekolahnya online kalau pagi-pagi saya kasih mandi dulu, sama saya suruh makan baru kalau saya mau berangkat kerja saya antar di rumahnya Uwa nya saya titipkan, kalau sekolahnya paling cuma dikasih tugas kadang saya bantu kerjakan malam". (wawancara dengan ibu Rina 19 Agustus 2020).

Berdasarkan hasil wawancara diatas pada pagi hari sebelum berangkat bekerja ibu Rina mengurus anaknya yang masih SD kelas 1 terlebih dahulu, dengan memandikan dan menyiapkan makanan baru kemudian ibu Rina menitipkan anaknya tersebut kepada uwa nya (kakak dari ibu Rina), ibu Rina juga tetap membantu anaknya mengerjakan tugas sekolahnya namun hanya pada malam hari ketika ibu Rina sudah pulang kerja dan berada di rumah.

\section{2) Partner Ayah}

Selain mengasuh dan mendidik anak ibu juga menjadi partner ayah dalam mendidik dan mengasuh anak-anaknya. Bahkan banyak pula ibu berperan membantu ayah dalam mencari nafkah. Maka ibu ialah partner ayah dalam segala hal, baik di rumah ataupun di luar demi berkelangsungan keluarganya. Dengan demikian ibu menjadi partner ayah dalam memenuhi kebutuhan keluarganya dengan bekerja sebagai buruh kasar pada PT. Cipta Agung Manis (CAM), hal ini dapat dilihat pada ibu rumah tangga di Desa Bumi Raya yang bekerja sebagai buruh kasar pada PT. Cipta Agung Manis. Berikut pernyataan dari informan atas nama ibu Sunarti yaitu:

"suami saya kan kerja juga kaya saya jadi kalau ngurus rumah sama anak-anak kita kerja sama kaya kalau saya masak kerja suami saya yang nyuci piring yaa pokoknya baku bantulah karena kita sama- 
sama kerjanya". (wawancara dengan ibu Sunarti 19 Agustus 2020).

Berdasakan hasil wawancara diatas ibu Sunarti selalu bekerja sama dalam baik dalam bekerja dan juga mengurus anakanak serta rumah karena suami dari ibu Sunarti juga bekerja sama dengan pekerjaan ibu Sunarti sehingga ketika di rumah mereka juga bekerja sama dimana ketika ibu Sunarti masak maka suaminya mencuci piring, dengan demikian ibu Sunarti dan suaminya bisa saling bantu dalam segala hal.

\section{3) Manajer Keluarga/pengatur kebutuhan keluarga}

Ketika ayah keluar rumah mencari nafkah ibu adalah manajer keluarga yang berperan penting di rumah. Sebagai manajer, ibu berperan mengatur kebutuhan dapur, kebersihan rumah, sampai dengan kebutuhan anak dan ayah. Meskipun dalam hal ini ibu juga ikut bekerja namun ibu tetap bisa menjadi manajer keluarga. Berikut pernyataan dari informan atas nama ibu Sutijem yaitu:

"yaa kalau saya mau bekerja pagipagi biasa saya kepasar dulu beli sayuran, ikan, bumbu-bumbu dapur sama keperluan lainnya baru habis itu masak, bersih-bersih, menyiapkan kebutuhan suami sebelum berangkat kerja sama kebutuhan anak-anak, baru kalau sudah selesai semuanya saya berangkat kerja. Kalau pulang kerja juga begitu saya masak buat makan malam sama bersih-bersih rumah juga". (wawancara dengan ibu Sutijem 21 Agustus 2020).

Berdasarkan hasil wawancara diatas ibu Sutijem menjelaskan bahwa sebelum berangkat bekerja informan akan mengurus segala kebutuhan dapur dengan pergi kepasar untuk memebeli segala kebutuhan dapur dan juga mengurus anakanak dan suaminya, seperti masak, bersihbersih. Begitu juga setelah pulang kerja maka informan akan memasak untuk makan malam dan beres-beres rumah.

\section{4) Mentri}

\section{Keluarga/Bendahara Keluarga}

Keuangan

Selain mengurus kebutuhan dapur, anak-anak dan suami ibu juga merupakan mentri keuangan keluarga dimana setiap keungan keluarga diatur oleh ibu dari kebutuhan-kebutuhan dapur, listrik, internet, cicilan, telephone, PAM, kebutuhan sekolah anak sampai kebutuhan yang tak terduga. Berikut pernyataan dari informan atas nama ibu Lis yaitu:

"iya,,, saya yang kelola uang, uang ini untuk kebutuhan ini, yang ini kebutuhan ini kalau untuk pembayaran listrik saya titipkan sama anaksaya yang paling besar untuk dibayarkan sama orang yang narikin uang listrik, kalau uang paket data internet, cicilan-cicilan kaya arisan sama cicilan lainnya, PAM, sama anak sekolah saya sendiri yang pergi bayarkarena kalau itukan anak saya tidak tahu”. (wawancara dengan ibu Lis 22 Agustus 2020).

Berdasarkan hasil wawancara diatas ibu Lis menjelaskan bahwa dirinya lah yang mengelola keuangan keluarga dan mengatur segala kebutuhan dari mulai kebutuhan dapur dimana ibu harus pergi ke pasar terlebih dahulu untuk belanja kebutuhan dapur sebelum berangkat kerja, membayar listrik, paket data internet untuk anaknya belajar, cicilan-cicilan seperti arisan, PAM, dan anak sekolah. 


\section{5) Pemberi Tauladan}

Seorang ibu juga harus bisa menjadi tauladan yang baik untuk anak-anaknya, karena anak umumnya memiliki kecenderungan dalam meniru orang-orang terdekatnya. Dalam hal ini ibu adalah sosok yang paling sering ditemuinya. Maka perilaku ibu yang baik akan menjadi cermin bagi perilaku anaknya. Untuk itulah ibu harus berperan sebagai pemberi tauladan yang baik bagi anak-anaknya. Karena bagaimanapun, anak akan meniru apa yang dilakukan oleh orang tuanya. Berikut pernyataan dari informan atas nama ibu Sunarti yaitu:

"kita namanya juga orang tua pasti harus bisa jadi tauladan, yaa walaupun kita jarang sama anakanak paling malam ketemunya sampe pagi tapi tetep harus bisa ngajarin yang baik-baik sama ngomongin yang baik dan benar juga supaya lama-lama anak-anak saya terbiasa ngomong yang baikbaik juga, kita juga biasakan mereka belajar mandiri kadang kalau saya lagi kerja anakanak sebelumnya sudah saya kasih tugas kaya nyapu rumah sama nyuci piring tapi semakin kesini mereka sudah terbiasa ngerjain tugas rumah walau ndak di kasih tau”. (wawancara dengan ibu Sunarti 19 Agustus 2020).

Berdasarkan hasil wawancara diatas ibu Sunarti menjelaskan bahwa dirinya tetap harus bisa menjadi tauladan bagi anak-anaknya meskipun dirinya jarang berada di rumah karena bekerja, meskipun hanya dengan mengajari dan berbicara hal-hal yang baik ketika bersama anak-anaknya dirinya berharap anaknya bisa meniru hal baik tersebut dan ibu Sunarti juga biasa mengajari anak-anaknya mandiri dengan memberikan tugas seperti mencuci piring dan menyapu rumah kepada anak-anaknya dengan demikian anak- anaknya sudah terbiasa dengan tugas tersebut dan mengerjakan tugas tersebut tanpa di beri tahu.

\section{6) Perawat Keluarga}

Ibu juga berperan sebagai perawat bagi keluarganya. Seperti merawat anakanaknya yang masih bayi, hingga menyiapkan kebutuhan ayah dan anakanak menjelang sekolah. Belum lagi jika mereka sakit, ibu adalah perawat yang sangat cermat dan sabar karena di dasari oleh cinta kasih yang tulus. Selain sebagai perawat, ibu juga adalah seorang dokter yang kadang harus mengupayakan kesembuhan dan menjaga putra putri nya dari berbagai hal yang mengancam kesehatan. Tidak hanya anak-anaknya tapi juga partnernya yaitu ayah, ia harus menjamin keluarganya sehat. Berikut pernyataan dari informan atas nama ibu Sunarti yaitu:

"kalau anak apa suami saya sakit yaa saya berhenti dulu itu kalau sakitnya parah kalau cuma demamdemam biasa yaa ndak berhenti kerja paling saya siapkan obat apa yang mau di minum nanti siang baru di titipkan sama neneknya kalau anak saya yang kecil sakit". (wawancara dengan ibu Wartiah 19 Agustus 2020).

Berdasarkan wawancara diatas ibu Wartiah mengatakan jika anaknya atau suaminya bekerja maka ibu Wartiah akan izin untuk tidak bekerja jika sakitnya parah namun jika hanya demam-demam biasa ibu Wartiah tetap bekerja namun ibu Wartiah tetap menyiapkan obat yang akan diminum dan kemudian menitipkan anaknya yang sakit ke rumah neneknya.

Dengan demikian meskipun mereka bekerja seharian sebagai buruh kasar pada PT. Cipta Agung Manis (CAM) dan hanya memiliki waktu yang sangat kurang untuk bersama keluarga yaitu pada 
sore sampai dengan pagi hari sehingga mereka menggunakan waktu yang ada tersebut dengan sangat maksimal yaitu dengan memenuhi segala kebutuhan suami dan anak-anaknya dan melaksanakan tugas-tugasnya sebagai seorang ibu rumah tangga yaitu mulai dari mengasuh dan mendidik anaknya, menjadi partner suaminya, menjadi manajer keluarga, menjadi mentri keuangan keluarga, pemberi tauladan bagi anak-anaknya, menjadi psikolog keluarganya, menjadi perawat dan dokter bagi keluarganya yang sakit.

\section{7) Peran Prouktif}

Dalam penelitian Haslianda dkk, (2019:891-892) seiring dengan perkembangan jaman serta dipengaruhi oleh emansipasi wanita maka peran wanita pun semakin berkembang. Kaum wanita tidak hanya berperan di dalam sektor domestik/reproduktif saja, namun wanita berperan juga dalam sektor produktif/dilingkungan kerja. Dahulu kaum wanita dewasa hanya memegang peran dalam keluarga, namun dewasa ini banyak sekali wanita yang memainkan peran dalam dunia kerja untuk mendapatkan nafkah. Kaum wanita dapat menduduki jabatan yang tidak bersifat tradisional (berbeda dengan peran wanita di rumah), namun mereka tidak dapat ingkar dari tanggung jawab rumah tangga yang sifatnya tradisional. Berikut pernyataan dari informan atas nama ibu Sunarti yaitu:

\footnotetext{
"saya bekerja disini sudah 6 bulan alasannya yaa karena penghasilan suami tidak mencukupi akhirnya saya bekerja kalau mencukupi sih saya mending diam di rumah urus anak walaupun awalnya saya tidak di izinin suami tapi lamalama di izinin karena bagaimana lagi penghasilannya juga ndak
}

\begin{abstract}
mencukupi kebutuhan, kalau penghasilannya sama $R p$ 500.000/minggu itu juga kalau nanam apa mupuk kalau cabut ya paling 300.000/minggu, tapi sekarang yaa Alhamdulillah karena saya juga kerja jadi kebutuhan bisa terpenuhi bahkan bisa belikan anak HP buat belajar online nya". (hasil wawancara dengan ibu Watirah 19 Agustus 2020)
\end{abstract}

Berdasarkan wawancara diatas ibu Wartirah mengatakan bahwa dirinya sudah bekerja di PT. CAM selama 6 bulan, dirinya juga mengatakan alasan mengapa dirinya bekerja di PT. CAM bahwa karena penghasilan suaminya tidak memenuhi kebutuhan keluarganya sehingga dirinya juga ikut membantu mencari nafkah dengan bekerja sebagai buruh kasar meskipun awalnya ibu Watirah tidak mendapat izin dari suaminya namun seiring dengan berjalanya waktu ibu Watirah mendapatkan izin dari suaminya, ibu Watirah juga mengatakan bahwa penghasilannya jika pekerjaan yang di kerjakan menanam dan memupuk bisa sampe 500.000/minggu tapi jika mencabut ubi penghasilannya hanya sekitar 300.000/minggu, dengan dirinya bekerja sekarang ibu Watirah mengatakan bahwa kebutuhan keluarga sudah bisa terpenuhi dan bahwan dirinya bisa membelikan anaknya HP untuk belajar online.

Hal tersebut sesuai dengan keterangan yang disampaikan oleh kepala lapangan ibu Warinti mengenai penghasilan para ibu rumah tangga yang bekerja sebagai buruh di PT. Cipta Agung Manis (CAM), mengatakan bahwa:

"di sinikan sistem kerjanya borongan, kalau untuk menanam sama memupuk memang lumayan penghasilannya karena di hitung 
perhektar yaitu 1 Juta/hektar dan mereka dalam satu kelompok bisa menyelesaikan satu hektar/harinya, tapi untuk mencabut dihitung perton yaitu 150.000/ton untuk satu harinya mereka kadang hanya bisa dapat 2 ton/kelompok jadi ibu-ibu memang lebih suka menanam sama memupuk karena mudah dan lebih banyak hitungannya dibandingkan mencabut". (hasil wawancara dengan ketua lapangan ibu Warinti 21 Agustus 2020)

Dari hasil wawancara dengan kepala lapangan yaitu ibu Warinti menjelaskan bahwa penghasilan dari bekerja sebagai buruh kasar pada PT. Cipta Agung Manis (CAM) lebih banyak penghasilan dari menanam dan memupuk dibandingkan dengan mencabut karena mencabut lebih sedikit hitungannya yaitu hanya Rp 150.000/ton dimana dalam sehari para ibu-ibu yang bekerja hanya dapat 2 ton saja per kelompoknya sedangkan menanam dan memupuk hitungannya sebesar $\mathrm{Rp} 1$ juta/hektar dan satu kelompok ibu-ibu yang bekerja bisa dapat sampe satu hektar/harinya.

Dengan demikian bahwa ibu rumah tangga yang bekerja sebagai buruh kasar pada PT. Cipta Agung Manis (CAM) dapat membantu suami dalam memenuhi kebutuhan keluarga meskipun ada pekerjaan yang penghasilannya tidak sesuai dengan apa yang kerjakan yaitu seperti mencabut ubi dimana pekerjaan tersebut merupakan pekerjaan yang paling melelahkan dan sulit namun penghasilan yang peroleh hanya 300.000/minggu di bandingkan dengan memupuk dan menanam ubi dengan pekerjaan yang terbilang ringan namun penghasilannya cukup banyak yaitu 500.000/minggu. Namun mereka tetap bersyukur karena berkat pekerjaan tersebut mereka bisa membantu suami mencari nafkah bahkan mereka bisa sampe membeli barang yang sebelumnya mereka tidak memiliki seperti kursi sofa dan HP untuk anaknya belajar online.

\section{8) Kondisi Sosial Ekonomi Keluarga 1) Pendidikan}

Pendidikan adalah usaha sadar dan terencana untuk mewujudkan suasana belajar dan proses pembelajaran agar peserta didik secara aktif mengembangkan potensi dirinya untuk memiliki kekuatan spiritual keagamaan, serta keterampilan yang diperlukan dirinya, masyarakat, bangsa dan Negara (UU RI No. 20 tahun 2003, tentang Serikat Pekerja Nasional). dalam Wurdiyanti (2016: 13) menurut Fuad Ihsan tingkat atau jenjang pendidikan adalah tahap pendidikan yang berkelanjutan yang ditetapkan berdasarkan tingkat perkembangan peserta didik, tingkat kerumitan bahan pengajaran dan cara menyajikan bahan pengajaran. Jenjang pendidikan sekolah terdiri dari pendidikan dasar, pendidikan menengah, dan pendidikan tinggi. Berikut pernyataan informan atas nama Ibu Rani yaitu:

"Pendidikan terakhir saya SMP
ndak saya lanjutkan karena orang
tua ndak ada biaya, anak saya ada
2 yang pertama SMP kelas l yang
kedua SD kelas 1 anak saya yang
pertama sih inginnya anak saya
sekolahnya pada sampe kuliah tapi
yaa ndak tau nanti semoga ada
rezeki, sekarang juga
alhamdulillah saya bisa kerja di
PT. CAM bantu-bantu suami cari
uang buat kebutuhan sekolahanak-
anak sama makan sehari-hari,
apalagi sekarang anak-anak
sekolahnya pada sekolah online
jadi harus pake HP tadinyacuma
punya HP citul (komuniketer)
sekarang bisa belikan HP yang


bagus buat belajar anak-anak”. (wawancara dengan ibu Rani 19 Agustus 2020).

Berdasarkan hasil wawancara diatas dengan ibu Rani beliau mengatakan bahwa pendidikan terakhirnya SMP beliau tidak melanjutkannya karen tidak memiliki biaya, dan sekarang ibu Rani memiliki dua anak dimana anak pertamanya duduk di kelas 1 SMP dan anak keduanya duduk di kelas 1 SD, anak pertama ibu Rani memiliki keinginan untuk bisa sekolah sampai bangku kuliah, menurut ibu Rani beliau bersyukur bisa kerja di PT. CAM karena bisa membantu suaminya mencari nafkah untuk memenuhi kebutuhan sekolah anak-anaknya dan makan sehari-hari, ibu Rani juga mengatakan bahwa saat ini anakanaknya sekolahnya online sehingga membutuhkan HP bagus untuk sekolah anak-anaknya sehingga ibu Rani membelikan anaknya HP untuk sekolah online dan belajar.

Dengan demikian pendidikan merupakan faktor penting untuk memiliki pekerjaan yang lebih baik dimana pendidikan para ibu rumah tangga yang bekerja sebagai buruh kasar pada PT. Cipta Agung Manis (CAM) kebanyakan hanyalah lulusan SMP. Meskipun demikian dengan bekerjanya ibu rumah tangga sebagai buruh kasar pada PT. CAM mampu memberikan fasilitas pendidikan kepada anak-anak mereka dengan baik.

\section{2) Pendapatan}

Pendapatan adalah segala penghasilan baik berupa uang atau barang yang sifatnya regular dan yang diterima biasanya sebagai balas jasa atau kontraprestasi. Dalam penelitian ini yang dimaksud dengan pendapatan adalah penghasilan berupa uang yang telah di satukan antara penghasilan istri dan suami yang diterima sebagai balas jasa dari bekerja sebagai buruh kasar pada PT. Cipta Agung Manis (CAM) apakah telah mengalami peningkatan pendapatan atau tidak. Berikut pernyataan informan atas nama ibu Sunarti yaitu:

"saya kerja di PT. CAM ini samasama dengan suami saya jadi buruh kasar, penghasilan saya kan sekitar 500.000/minggu karena suami saya kerja sama-sama saya di PT. CAM jadi penghasilan kami kalau di gabung sekitar 1 Juta/minggu Alhamdulillah sudah cukup buat memenuhi kebutuhan sehari-hari keluarga saya". (Wawancara dengan ibu Sunarti 19 Agustus 2020)

Berdasarkan hasil wawancara dengan ibu Sunarti mengatakan bahwa ibu Sunarti bekerja di PT. CAM sebagai buruh kasar bersama-sama dengan suaminya, dimana penghasilan ibu Sunarti ialah sekitar 500.000/minggu jadi jika di satukan antara pendapatan ibu Sunarti dan suaminya maka sekitar $1 \mathrm{Juta} /$ minggu dan menurut ibu Sunarti penghasilan tersebut sudah cukup untuk memenuhi kebutuhan sehari-hari keluarganya.

Dengan demikian pendapatan antara ibu rumah tangga yang bekerja sebagai buruh kasar pada PT. Cipta Agung Manis (CAM) apabila di satukan dengan pendapatan suami mereka sudah cukup untuk memenuhi kebutuhan keluarga mereka.

\section{3) Kepemilikan Asset Rumah}

Menurut pengertiannya, aset adalah sumber ekonomi yang diharapkan memberikan manfaat di kemudian hari. Jadi, aset rumah tangga adalah jumlah kekayaan yang dimiliki oleh keluarga dalam bentuk sumber ekonomi yang memberikan manfaat. Rumah dapat mewujudkan suatu tingkatan sosial ekonomi bagi keluarga yang menempati. 
Apabila rumah tersebut berbeda dalam hal ukuran dan kualitas rumah. Rumah dengan ukuran besar, permanen dan milik pribadi dapat menunjukan bahwa kondisi sosial ekonominya tinggi, berbeda dengan rumah yang kecil, semi permanen dan menyewa menunjukan bahwa sosial ekonominya rendah. Berikut pernyataan informan atas nama ibu Watirah yaitu:

"rumah saya luasnya $8 \times 10$ meter kondisinya masih pake papan dindingnya, kalau lantainya masih semen terus atapnya sudah pake seng yaa lumayan lah walaupun masih pake papan dindingnya tapi saya sama keluarga nyaman ninggalinnya karenakan rumah sendiri dari pada numpang apa ngontrak, saya tinggal dengan suami sama 3 anak saya jadi ada 5 orang yang tinggal di rumah saya". (Wawancara dengan ibu Watirah 19 Agustus 2020)

Berdasarkan wawancara dengan ibu Watirah di atas menjelaskan bahwa ukuran rumahnya $8 \times 10$ meter dengan kondisi masih berdindingkan papan, berlataikan semen dan beratapkan seng, dengan kondisi rumahnya yang demikian ibu Watirah bersama keluarganya merasa nyaman tinggal di rumah tersebut karena rumah tersebut merupakan rumah sendiri bukan rumah hasil menyewa maupun menumpang kepada orang. Jumlah anggota keluarga yang tinggal di rumah tersebut sebanyak 5 orang yaitu ibu Watirah sendiri, suami dan ketiga anak mereka.

Dengan demikian meskipun kondisi rumah sebagian besar dari para ibu rumah tangga yang bekerja sebagai buruh kasar pada PT. Cipta Agung Manis (CAM) masih berdindingkan papan, masih berlantaikan semen dan beratapkan seng namun mereka bersama keluarganya merasa nyaman tinggal di rumah meraka karena rumah tersebut merupakan rumah milik mereka peribadi bukan rumah hasil mengontrak ataupun menumpang pada orang lain.

\section{4) Pemenuhan Kebutuhan \\ Keluarga/Pengeluaran Keluarga}

Pemenuhan kebutuhan atau pengeluaran setiap keluarga dengan keluarga yang lain tidaklah sama dan selalu berbeda-beda. Keluarga dengan jumlah anggota yang besar, pengeluarannya berbeda dengan keluarga yang anggota keluarganya sedikit.

"Alhamdulillah kebutuhan

keluarga saya terpenuhi kalau untuk makan tiap hari makan ikan, minum juga tetep bisa beli air galon untuk minum sama baju seharihari Alhamdulillah juga terpenuhi. Kebutuhan sekolah anak-anak saya juga terpenuhi kaya baju sekolah selalu beli setiap setahun sekali karena biasanya sudah ndak cukup, sama buku-buku pelajaran juga selalu beli baru tiap semester, pembayaran spp juga selalu di bayartiap bulannya. Anak saya ada dua dan dua-duanya sekolah dua-duanya juga selalu terpenuhi kebutuhan sekolahnya". (Wawancara dengan ibu Rina 19 Agustus 2020)

Berdasarkan wawancara dengan ibu Rina di atas mengatakan bahwa kebutuhan keluarganya Alhamdulillah selalu terpenuhi kaya kebutuhan makannya beliau mengatakan bahwa setiap hari makan ikan, untuk minumnya ibu Rina selalu membeli air galon dan juga pakaian sehari-hari juga terpenuhi. Begitu pula kebutuhan pendidikan anak-anaknya juga terpenuhi dari pakaian sekolah yang selalu ganti tiap tahun, buku-buku untuk sekolah selalu beli setiap semester dan juga pembayaran spp juga selalu di bayarnya setiap bulan, meskipun anak ibu Rina yang bersekolah ada dua namun kedua anaknya 
tetap sama-sama terpenuhi kebutuhan sekolahnya.

Dengan demikian kebutuhan keluarga para ibu rumah tangga yang bekerja sebagai buruh kasap pada PT. Cipta Agung Manis (CAM) dapat terpenuhi karena suami mereka mendapatkan tambahan penghasilan yang di peroleh dari si istri yang bekerja tersebut, baik kebutuhan sehari-hari mereka seperti makan, minum, pakaian sehari-hari dan juga kebutuhan untuk pendidikan anakanak mereka juga dapat terpenuhi oleh mereka.

\section{KESIMPULAN}

Berdasarkan hasil penelitian dan pembahasan dalam penelitian ini maka penulis menyimpulkan bahwa:

1. Peran Ibu Rumah Tangga Pekerja Buruh Kasar: meskipun mereka bekerja seharian sebagai buruh kasar pada PT. Cipta Agung Manis (CAM) dan hanya memiliki waktu yang sangat kurang untuk bersama keluarga yaitu pada sore sampai dengan pagi hari sehingga mereka menggunakan waktu yang ada tersebut dengan sangat maksimal yaitu dengan memenuhi segala kebutuhan suami dan anak-anaknya dan melaksanakan tugas-tugasnya sebagai seorang ibu rumah tangga yaitu mulai dari mengasuh dan mendidik anaknya, menjadi partner suaminya, menjadi manajer keluarga, menjadi mentri keuangan keluarga, pemberi tauladan bagi anak-anaknya, menjadi psikolog keluarganya, menjadi perawat dan dokter bagi keluarganya yang sakit.

2. Kondisi Sosial Ekonomi Keluarga: masyarakat di Desa Bumi Raya Kecamatan Andoolo khususnya para keluarga yang istrinya juga ikut bekerja sebagai buruh kasar pada PT. Cipta Agung Manis (CAM) untuk membantu suami mereka mencari nafkah telah dapat meningkatkan kondisi sosial ekonomi keluarga sehingga tingkat kesejahteraan keluarga telah lebih meningkat yaitu pendidikannya, pendapatannya, aset rumah yang dimiliki dan juga pemenuhan kebutuhan keluarga/pengeluaran keluarga. Meskipun dengan mereka bekerja mereka hanya memiliki waktu sedikit untuk bersama keluarga namun dengan bekerja mereka juga telah dapat berkontribusi untuk meningkatkan pendapatan keluarga.

Berdasarkan hasil penelitian dan pembahasan dalam penelitian ini maka penulis menyimpulkan bahwa:

1. Peran Ibu Rumah Tangga Pekerja Buruh Kasar: meskipun mereka bekerja seharian sebagai buruh kasar pada PT. Cipta Agung Manis (CAM) dan hanya memiliki waktu yang sangat kurang untuk bersama keluarga yaitu pada sore sampai dengan pagi hari sehingga mereka menggunakan waktu yang ada tersebut dengan sangat maksimal yaitu dengan memenuhi segala kebutuhan suami dan anak-anaknya dan melaksanakan tugas-tugasnya sebagai seorang ibu rumah tangga yaitu mulai dari mengasuh dan mendidik anaknya, menjadi partner suaminya, menjadi manajer keluarga, menjadi mentri keuangan keluarga, pemberi tauladan bagi anak-anaknya, menjadi psikolog keluarganya, menjadi perawat dan dokter bagi keluarganya yang sakit.

2. Kondisi Sosial Ekonomi Keluarga: masyarakat di Desa Bumi Raya Kecamatan Andoolo khususnya para keluarga yang istrinya juga ikut bekerja sebagai buruh kasar pada PT. Cipta Agung Manis (CAM) untuk membantu suami 
mereka mencari nafkah telah dapat meningkatkan kondisi sosial ekonomi keluarga sehingga tingkat kesejahteraan keluarga telah lebih meningkat yaitu pendidikannya, pendapatannya, aset rumah yang dimiliki dan juga pemenuhan kebutuhan keluarga/pengeluaran keluarga. Meskipun dengan mereka bekerja mereka hanya memiliki waktu sedikit untuk bersama keluarga namun dengan bekerja mereka juga telah dapat berkontribusi untuk meningkatkan pendapatan keluarga.

\section{DAFTAR PUSTAKA}

Upe, Ambo 2016. Metode Penenlitian Sosial. Kendari . Literacy Institute.

Bakri, Maria H 2002. Asuhan Keperawatan

Keluarga. Yogyakarta. PT. Pustaka Baru.

Yuli Astuti, Wurdiyanti 2016. Pengaruh

Kondisi Sosial Ekonomi Keluarga Terhadap Minat Belajar Siswa

SMK YPKK 3 Sleman. Program Studi Pendidikan Ekonomi. Fakultas

Ekonomi. Universitas Negri

Yogyakarta.

Haslianda dan dkk 2019. Peran Ganda

Dalam Keluarga Ibu Bekerja Di

Sektor Informal (Studi Di Desa

Epeesi Kecamatan Basala Kabuaten Konawe Selatan. Vol. 4, No.

3, hal. 891-892 